\title{
Analisis Risiko Produksi Bunga Krisan di Desa Sidomulyo Kota Batu
}

\author{
Siti Nur Fadlilah', Bambang Yudi Ariadi², Rahayu Relawati ${ }^{3}$ \\ ${ }^{1}$ PT Sentral Kemasindo Teguh Mojasari Mojokerto \\ ${ }^{2,3}$ Prodi Aagribisnis Universitas Muhammadiyah Malang, Jl. Raya Tlogomas 246, Malang \\ *Corresponding author: Sitinurfadlilah165@gmail.com
}

\begin{abstract}
This study aimed to analyze the income of chrysanthemum farming, and the effect of inputs on the risk of chrysanthemum production at Desa Sidomulyo, Batu City. The data were taken during May and June 2018, from one season that was last harvested The data were obtained through interviews with 34 farmers who were taken (by census method. The farm income was financially analyzed while the factors that influence the risk of chrysanthemum production were analyzed Cobb-Douglass and Just and Pope function. The analysis results showed that Chrysanthemum farming income is profitable and efficient, identified from the results of the R/C Ratio of 1.90. Meanwhile, the production inputs significantly affected the productivity of chrysanthemums are seeds, chemical fertilizers, and labor. While the factors significantly affected the risk of production is chemical fertilizers. The farmers are recommended to reduce the use of chemical fertilizers. Farmers also need to use the chemical fertilizers carefully, because they can cause plants poisoning and death thereby reducing production and farm income.
\end{abstract}

Keywords: farm income, risk analysis, chrysanthemum.

\section{INTISARI}

Penelitian ini bertujuan untuk menganalisis pendapatan usahatani bunga Krisan potong, dan pengaruh input-input produksi risiko produksi bunga Krisan potong di Desa Sidomulyo Kota Batu. Data penelitian selama bulan Mei dan Juni 2018 dari satu kali tanam yang dipanen terakhir. Data didapatkan melalui wawancara terhadap 34 petani yang diambil secara sensus. Pendapatan usahatani dianalisis secara finansial, sedangkan faktor-faktor yang mempengaruhi risiko produksi bunga Krisan dianalisis dengan fungsi produksi Cobb-Douglass dan Just and Pope. Hasil analisis menunjukkan bahwa pendapatan usahatani bunga Krisan potong menguntungkan dan efisien dilihat dari hasil R/C Ratio sebesar 1,90. Faktor-faktor produksi secara nyata mempengaruhi produktivitas bunga Krisan potong yaitu bibit, pupuk kimia, dan tenaga kerja, sedangkan faktor-faktor yang secara nyata mempengaruhi risiko produksi adalah pupuk kimia. Rekomendasi yang diberikan adalah petani harus mengurangi penggunaan pupuk kimia. Petani juga harus berhati-hati dalam penggunaan pupuk kimia yang berlebihan karena dapat menyebabkan tanaman keracunan dan mati sehingga menurunkan produksi dan pendapatan usahatani.

Kata kunci: pendapatan usahatani, risiko, bunga Krisan potong.

\section{PENDAHULUAN}

Krisan merupakan salah satu komoditas tanaman hias yang banyak dibudidayakan di Jawa Timur. Tahun 2016 luas panen tanaman Krisan di Jawa Timur sudah mencapai 6.318.227 $\mathrm{m}^{2}$ dengan produksi bunga Krisan potong sebanyak 129.829.313 tangkai per tahun (BPS 2016). Sentra produksi bunga Krisan Jawa Timur terdapat di empat wilayah yaitu Pasuruan, Kota Batu, Kabupaten Malang, dan Kabupaten Mojokerto. Tabel 1 menunjukkan produksi tanaman Krisan tahun 2006-2016 di daerah sentra produksi. 
ISSN : 2622-6154 (print)

Tabel 1. Wilayah Produksi Tanaman Krisan (Tangkai)

\begin{tabular}{lllll}
\hline Tahun & Pasuruan & Batu & Malang & Mojokerto \\
\hline 2006 & 441.700 & 194.326 & 198.699 & 31.400 \\
2007 & 1.769 .470 & 6.000 .000 & 75.000 & 574.800 \\
2008 & 1.440 .000 & 0 & 8.366 .061 & 69.390 \\
2009 & 9.401 .400 & 465.444 & 15.171 .845 & 116.245 \\
2010 & 0 & 0 & 0 & 0 \\
2011 & 0 & 0 & 0 & 0 \\
2012 & 0 & 0 & 0 & 0 \\
2013 & 0 & 0 & 0 & 0 \\
2014 & 0 & 0 & 0 & 0 \\
2015 & 74.330 .000 & 32.977 .893 & 5.583 .900 & 1.056 .628 \\
2016 & 86.247 .100 & 35.849 .150 & 5.465 .000 & 2.193 .506 \\
\hline
\end{tabular}

Sumber: Badan pusat Statistik dan kementerian Pertanian (2018)

Tabel 1 menunjukkan bahwa pada tahun 2016 produksi Krisan tertinggi berada di Pasuruan, di peringkat ke dua yaitu Kota Batu, peringkat ketiga Kabupaten Malang dan diperingkat ke empat Kabupaten Mojokerto. Besarnya jumlah produksi bunga Krisan potong belum menjamin stabilnya produktivitas. Gambar 1 merupakan gambar grafik produktivitas bunga Krisan di Pasuruan, Kota Batu, Kabupaten Malang, dan Kabupaten Mojokerto pada data tahun 2006-2016.

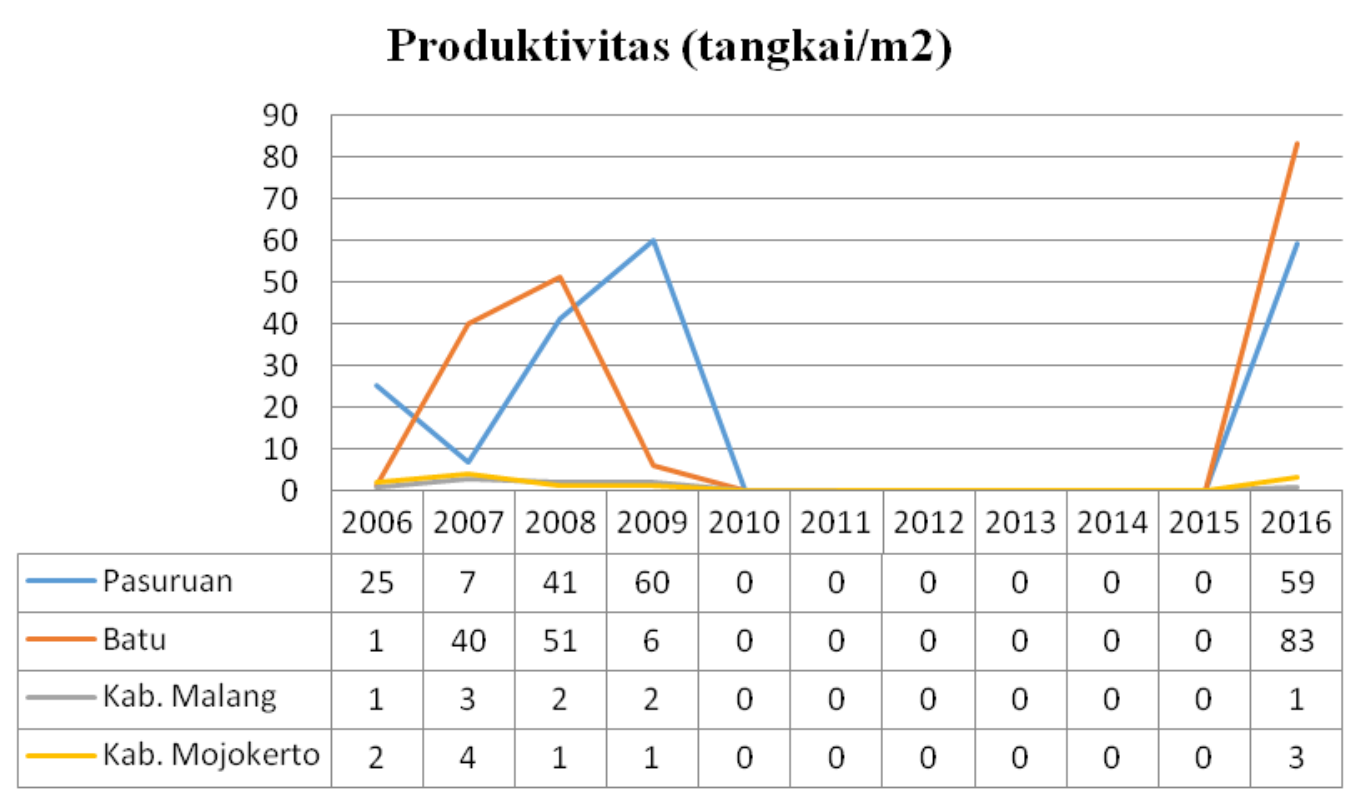

Gambar 1. Produktivitas Bunga Krisan di Pasuruan, Batu, Kabupaten Malang, dan Kabupaten Mojokerto pada tahun 2006-2016

Sumber: Badan pusat Statistik dan kementerian Pertanian (2018)

Perbedaan produktivitas bunga Krisan di Jawa Timur sangat terlihat produktivitas terendah adalah 0 tangkai dan produktivitas tertinggi yaitu 83 tangkai. Berdasarkan Tabel 1, pada tahun 2016 Pasuruan merupakan penghasil Krisan terbesar dengan produksi sebanyak 86.247.100 tangkai. Namun pada Gambar 1 produktivitas Krisan pada tahun 2016 menunjukkan wilayah Batu menduduki peringkat pertama dengan 
produktivitas tertinggi yaitu 83 tangkai $/ \mathrm{m}^{2}$. Produktivitas Krisan di Batu pada tahun 2006 sebanyak 1 tangkai $/ m^{2}$, fluktuasi produktivitas yang signifikan ini mengindikasikan adanya risiko produksi yang dialami petani. Fluktuasi produktivitas ini akan berdampak pada pendapatan usahatani tidak menentu, dan bila tidak segera diatasi mengakibatkan penurunan pendapatan. Oleh karena itu dibutuhkan informasi untuk mengetahui faktor-faktor apa saja yang mempengarui risiko produksi bunga Krisan di Sidomulyo Kota Batu. Tabel 1 dan Gambar 1 menunjukkan pada tahun 2010 sampai 2015 terjadi kekosongan data yang disebabkan oleh ketidaktersediaan data pada website BPS dan Pusdatin pertanian.

Kurniati (2012) menganalisis variabel lahan, benih, tenaga kerja, urea, tsp, dan herbisida dengan metode analisis koefisien variasi dan regresi model multiplicative heteroscedasticity. Hasil analisis menunjukkan bahwa risiko produksi pada lahan $<1 \mathrm{Ha}$ lebih tinggi dibandingkan luas lahan $1 \mathrm{Ha}$. Variabel bebas tenaga kerja berpengaruh nyata menurunkan produksi jagung dan berpengaruh nyata menurunkan risiko produksi. Penelitian ini berbeda dalam hal komoditas, sedikit perbedaan variabel dependen (TSP dan herbisida) dan ada penambahan analisis koefisien variasi.

Darwanto et al (2011) menganalisis variabel benih, pupuk urea, pupuk SP36, pupuk KCL, pupuk organik, pestisida, tenaga kerja, jarak dari sawah, jarak dari sarana produksi, dummy musim tanam, dummy varietas kedelai, dummy jarak tanam, dummy tipe lahan, dan dummy status lahan dengan metode analisis koefisien variasi dan regresi model multiplicative heteroscedasticity. Hasil analisis menunjukkan bahwa pada lahan produktivitas tinggi $(\geq 1,5 \mathrm{ton} / \mathrm{ha})$ variabel pupuk KCL dan penerapan jarak tanam (40 x $10 \mathrm{~cm}$ ) pada sawah irigasi, variabel benih kedelai pada sawah tadah hujan, dan variabel pupuk urea pada tegalan, secara nyata berpengaruh pada peningkatan produksi dan menurunkan risiko produksi kedelai. Lahan produktivitas sedang (1,00-1,49 ton/ha) variabel bebas yang berpengaruh nyata dalam meningkatkan produksi dan menurunkan risiko adalah pupuk urea dan jarak tanam $(40 \times 15 \mathrm{~cm})$ pada sawah irigasi, penggunaan varietas unggul pada sawah tadah hujan, dan jarak tanam $(40 \times 10 \mathrm{~cm})$ pada tegalan. Lahan produktivitas rendah $(\leq 1.0 \mathrm{tan} / \mathrm{ha})$ variabel bebas yang berpengaruh nyata terhadap peningkatan produksi dan penurunan risiko produksi adalah benih kedelai, varietas unggul, dan status lahan bagi hasil pada sawah tadah hujan dan pupuk KCL, tenaga kerja, dan status lahan bagi hasil pada tegalan sedangkan untuk sawah irigasi variabel bebas tidak berpengaruh nyata dalam meningkatkan produksi namun secara nyata menurunkan risiko produksi adalah benih kedelai, varietas unggul, jarak tanam $(40 \times 10 \mathrm{~cm})$, dan status lahan bagi hasil. Perbedaan penelitian ini adalah komoditas yang diteliti, beberapa perbedaan variabel bebas yang diuji dan penambahan analisis koefisien variasi.

Rinaldy et al (2015) menganalisis variabel luas lahan, benih, pupuk NPK, pupuk organik, pestisida, dan tenaga kerja dengan metode koefisien variasi dan regresi model multiplicative heteroscedasticity. Hasil analisis menunjukkan bahwa risiko produksi padi pada saat musim hujan lebih tinggi dari pada musim kemarau, dan risiko produksi sawah lebih tinggi pada lahan milik sendiri dibandingkan lahan sewa. Faktor yang secara nyata meningkatkan produksi padi dan menurunkan risiko produksi adalah variabel lahan dan pupuk organik. Perbedaan penelitian ini adalah komoditas yang digunakan padi dan penambahan analisa koefisien variasi.

Zakirin et al (2013) menganalisis variabel lahan, benih, urea, SP36, KCL, herbisida, umur petani, dan pendidikan dengan metode regresi linier berganda model 
fungsi produksi Cobb-Douglass dan fungsi produksi Just and Pope dan analisis one way anova. Hasil analisis menunjukkan bahwa faktor-faktor yang mempengaruhi produksi padi secara nyata adalah lahan, benih, urea, herbisida, tenaga kerja, umur petani, dan dummy tipe luapan B. Sedangkan untuk faktor-faktor yang mempengaruhi penurunan risiko secara nyata adalah lahan dan benih. Berdasarkan uji LSD dan standar deviasi risiko produksi luapan tipe B lebih rendah dibandingkan tipe A maupun C. Perbedaan penelitian ini adalah beberapa variabel bebas yang digunakan adalah urea, SP36, KCL, herbisida, umur petani, dan pendidikan, penambahan analisa one way anova, serta komoditas yang diteliti bukan padi tetapi bunga Krisan.

Fanani et al (2015) menganalisis variabel bibit, luas lahan, pupuk NPK, pupuk urea, pupuk tsp, pestisida, tenaga kerja, dummy (kemitraan dan non kemitraan) dengan metode fungsi produksi Just and Pope dan koefisien variasi. Hasil penelitian menunjukkan bahwa petani yang bermitra memiliki risiko harga lebih rendah dari petani non mitra serta risiko produksi yang dialami petani bermitra lebih rendah dibandingkan dengan petani non mitra, dan kemitraan mempunyai pengaruh yang nyata dalam mengurangi risiko produksi tembakau. Perbedaan penelitian ini adalah variabel bebas yang diteliti sebagian berbeda yaitu pupuk urea, pupuk TSP, dan variabel dummy, serta ada penambahan analisis koefisien variasi serta komoditas yang diteliti adalah tembakau

Rama et al (2016) menganalisis variabel lahan, benih, urea, NPK, herbisida, tenaga kerja, umur, dan pendidikan dengan metode fungsi produksi Just and Pope dan koefisien variasi. Hasil penelitian menunjukkan bahwa risiko produksi pada lahan basah lebih besar jika dibandingkan dengan risiko produksi lahan kering. Variabel luas lahan pada lahan basah secara nyata dapat meningkatkan produksi padi dan menurunkan risiko produksi padi, serta pada lahan kering luas lahan, herbisida, dan tenaga kerja keluarga secara nyata dapat meningkatkan produksi padi. Perbedaan penelitian ini adalah bebarapa variabel bebas yang diteliti berbeda yaitu urea, herbisida, umur, dan pendidikan, penambahan analisis koefisien variasi, serta komoditas yang diteliti adalah bunga Krisan.

Darmansyah et al (2017) menganalisis variabel luas lahan, jumlah tanaman, tenaga kerja, pupuk urea, pupuk NPK, dan pestisida dengan metode fungsi produksi Just and Pope. Hasil menunjukkan bahwa variabel yang secara nyata meningkatkan produksi Jeruk Siam adalah jumlah tanaman dan pupuk Urea sedangkan variabel luas lahan, tenaga kerja, pupuk Urea merupakan faktor-faktor yang menurunkan risiko produksi Jeruk Siam namun tidak berpengaruh nyata. Perbedaan penelitian ini adalah variabel bebas dan komoditas yang diteliti.

Analisis risiko produksi bunga Krisan potong sangat penting dilakukan. Penelitian yang dilakukan bertujuan untuk menganalisis pendapatan usahatani bunga Krisan potong serta menganalisis pengaruh penggunaan input usahatani bunga Krisan potong terhadap risiko produksi di Desa Sidomulyo Kota Batu. Hipotesis untuk tujuan ke dua yaitu di duga faktor-faktor bibit, pupuk kandang, pupuk kimia, pestisida, dan tenaga kerja, berpengaruh secara signifikan terhadap produktivitas bunga Krisan potong, dan diduga faktor-faktor tersebut berpengaruh secara signifikan terhadap risiko produksi bunga Krisan potong.

\section{METODE PENELITIAN}

Lokasi penelitian ditentukan dengan sengaja (purposive) dengan dasar pertimbangan bahwa Desa Sidomulyo Kota Batu merupakan salah satu daerah produksi 
bunga Krisan potong yang cukup tinggi. Pengumpulan data dilaksanakan pada bulan April, Mei dan Juni tahun 2018 untuk satu kali tanam yang dipanen terakhir. Pengambilan sampel petani Krisan potong ditetapkan dengan metode sensus (seluruh petani bunga Krisan potong Desa Sidomulyo menjadi responden penelitian). Analisis data meliputi: Analisis Pendapatan Usahatani Bunga Krisan Potong, analisis Regresi Cobb Douglas, serta analisis risiko produksi dari Just and Pope.

\section{Penerimaan usahatani}

Penerimaan usahatani adalah perkalian antara produksi yang diperoleh dengan harga jual (Soekartawi, 1995) secara matematis pernyataan ini dapat dirumuskan sebagai berikut:

TR $=$ Y. Py

\section{Biaya Usahatani}

Keterangan: $\mathrm{TR}=$ Total Penerimaan

$$
\begin{aligned}
& \mathrm{Y}=\text { Produksi } \\
& \mathrm{Py}=\text { Harga }
\end{aligned}
$$

Biaya usahatani adalah semua biaya pengeluaran yang digunakan oleh petani dalam suatu usahatani (Soekartawi, 1995). Total biaya usahatani dibagi menjadi dua yaitu biaya tetap (FC) dan biaya variabel (VC). Biaya tetap merupakan biaya yang tidak mempengaruhi besar kecilnya output yang dihasilkan, contohnya seperti peralatan, sewa lahan, pajak, dan listrik. Peralatan yang digunakan dalam kegiatan usahatani mempunyai nilai penyusutan sehingga dalam analisis pendapatan diperlukan perhitungan biaya penyusutan. Biaya penyusutan dirumuskan sebagai berikut:

$$
\begin{aligned}
& \text { Biaya Penyusutan: } \frac{N b-N s}{n} \\
& \text { Keterangan : } \mathrm{Nb}=\text { Nilai Pembelian (Rp) } \\
& \mathrm{Ns}=\text { Nilai Sisa (Rp) } \\
& \mathrm{n}=\text { Umur Ekonomis (tahun) }
\end{aligned}
$$

\section{Pendapatan Usahatani}

Pendapatan usahatani merupakan selisih antara penerimaan dan semua biaya yang digunakan. Secara sistematik analisis pendapatan dituliskan sebagai berikut (Soekartawi, 1995) :

$\mathrm{Pd}=\mathrm{TR}-\mathrm{TC}$

Keterangan : $\quad \mathrm{Pd}=$ Pendapatan Usahatani

$$
\mathrm{TR}=\text { Total Penerimaan }
$$$$
\mathrm{TC}=\text { Total Biaya }
$$

\section{$\mathrm{R} / \mathrm{C}$ ratio}

$\mathrm{R} / \mathrm{C}$ adalah singkatan dari Return Cost Ratio, atau dikenal sebagai perbandingan antara penerimaan dan biaya total. Secara matematik dituliskan sebagai berikut (Soekartawi, 1995):

$\mathrm{R} / \mathrm{C}$ ratio $=\frac{\text { Total Penerimaan }}{\text { Total Biaya }}$

Kriteria:

R/C Ratio > 1, usahatani efisien dan menguntungkan

$\mathrm{R} / \mathrm{C}$ Ratio $<1$, usahatani tidak efisien tidak menguntungkan

$\mathrm{R} / \mathrm{C}$ Ratio $=1$, usahatani impas. 


\section{Analisis Risiko Produksi}

Pengukuran risiko produksi diidentifikasi menggunakan nilai variance produktivitas, salah satu model yang dapat mengetahui variance produktivitas adalah model Just and Pope. Analisis risiko produksi diperoleh dari pendugaan terhadap fungsi produksi dan fungsi risiko (variance) produksi. Fungsi produksi yang digunakan dalam analisis ini adalah fungsi produksi Cobb-Douglas dalam bentuk logaritma natural. Adapun persamaan fungsi produktivitas bunga Krisan potong dan fungsi risiko produksi adalah:

Fungsi Produksi Rata - rata

$$
\begin{aligned}
& \operatorname{Ln} Y_{i t} \\
& \beta_{0}+\beta_{1} \operatorname{LnX} X_{1 i t}+\beta_{2} \operatorname{LnX} X_{2 i t}+\beta_{3} \operatorname{LnX} X_{3 i t}+\beta_{4} \operatorname{Ln} X_{4 i t}+\beta_{5} \operatorname{LnX} X_{5 i t}+\varepsilon
\end{aligned}
$$

Risiko Produksi:

$$
\sigma^{2} Y_{i t}=\left(Y_{i}-\hat{Y}_{i}\right)^{2}
$$

Risiko produksi merupakan residual dari model regresi (varians produksi) yang diperoleh dari selisih antara produksi actual dengan produksi hasil regresi.

Fungsi Risiko produksi

\begin{tabular}{|c|c|c|}
\hline $\begin{array}{l}\text { Y } \\
X_{1}\end{array} X_{2} \ldots X_{10}$ & $\begin{array}{l}= \\
=\end{array}$ & $\begin{array}{l}\text { Produktivitas Krisan Potong (tangkai / } 1000 \mathrm{~m}^{2} \text { ) } \\
\text { Input - input dalam produksi }\end{array}$ \\
\hline$X_{1}$ & $=$ & $\begin{array}{l}\text { Jumlah bibit yang digunakan per satu periode tanam } \\
\left(\text { tangkai/ } 1000 \mathrm{~m}^{2}\right)\end{array}$ \\
\hline$X_{2}$ & $=$ & $\begin{array}{l}\text { Jumlah pupuk kandang yang digunakan per satu periode } \\
\text { tanam }\left(\mathrm{Kg} / 1000 \mathrm{~m}^{2}\right)\end{array}$ \\
\hline$X_{3}$ & $=$ & $\begin{array}{l}\text { Jumlah pupuk kimia yang digunakan per satu periode tanam } \\
\left(\mathrm{Kg} / 1000 \mathrm{~m}^{2}\right)\end{array}$ \\
\hline$X_{4}$ & $=$ & $\begin{array}{l}\text { Jumlah pestisida yang digunakan per satu periode tanam } \\
\left(\text { Unit/1000 } \mathrm{m}^{2}\right)\end{array}$ \\
\hline$X_{5}$ & $=$ & $\begin{array}{l}\text { Jumlah tenaga kerja yang digunakan per satu periode tanam } \\
\left(\mathrm{HKSP} / 1000 \mathrm{~m}^{2}\right)\end{array}$ \\
\hline$\sigma^{2} Y$ & $=$ & Variance error produktivitas \\
\hline$\varepsilon$ & $=$ & Error \\
\hline $\mathrm{T}$ & $=$ & Musim \\
\hline I & $=$ & Petani responden \\
\hline$\beta, \theta$ & $=$ & Konstanta \\
\hline$\beta_{1}, \beta_{2, \ldots x} \beta_{10}$ & $=$ & Koefisin parameter dugaan $X_{1} X_{2,} \ldots X_{8}$ \\
\hline$\theta_{3,}, \theta_{4, \ldots x} \theta_{12}$ & $=$ & Koefisin parameter dugaan $X_{1} X_{2,} \ldots X_{8}$ \\
\hline
\end{tabular}

$$
\begin{aligned}
& \mathrm{Ln} \\
& \sigma^{2} Y_{i t}=\theta_{0}+\theta_{1} \varepsilon_{i t-1}^{2}+\theta_{2} \operatorname{Ln} \sigma^{2} \theta_{3} \operatorname{Ln} X_{1 i t-1}+\theta_{4} \operatorname{Ln} X_{2 i t-1}+ \\
& \theta_{5} \operatorname{Ln} X_{3 i t-1}+\theta_{6} \operatorname{Ln} X_{4 i t-1}+\theta_{7} \operatorname{Ln} X_{5 i t-1}+\varepsilon
\end{aligned}
$$

Keterangan : 


\section{HASIL DAN PEMBAHASAN}

\section{Pembahasan Analisis Finansial}

Analisis finansial merupakan analisis yang digunakan untuk menghitung komponen biaya-biaya yang digunakan dalam usahatani bunga Krisan potong mulai dari penanaman hingga output yang dihasilkan menggunakan data biaya rill yang dikeluarkan maupun yang diperhitungkan. Analisis finansial meliputi biaya variabel, biaya tetap, biaya total, penerimaan berbagai grade, pendapatan, serta $\mathrm{R} / \mathrm{C}$ ratio.

Tabel 2. Analisis Finansial

\begin{tabular}{|c|c|c|c|}
\hline No & Uraian & $\mathrm{Rp} / 1000 \mathrm{~m}^{2}$ & $\mathrm{Rp} / \mathbf{1 0 0 0 \mathrm { m } ^ { 2 }}$ \\
\hline & Bibit & $10.383 .147,06$ & \\
\hline & Pupuk kandang & $577.502,92$ & \\
\hline & Pupuk Kimia & $364.990,87$ & \\
\hline & Pestisida & $474.018,39$ & \\
\hline & Vitamin & $151.057,95$ & \\
\hline & Isolasi & $17.237,02$ & \\
\hline & Karet & $44.419,18$ & \\
\hline & Kertas & $576.470,00$ & \\
\hline & Tenaga Kerja & $5.755 .311,16$ & \\
\hline A. & Total Biaya Variabel & & 18.355.919,25,- \\
\hline & Sewa Lahan & $29,411.76$ & \\
\hline & Pajak & $66,626.02$ & \\
\hline & Listrik & $647,340.69$ & \\
\hline & Penyusutan Alat & $1,958,097.26$ & \\
\hline B. & Total Biaya Tetap & & 2.701.475,73,- \\
\hline C. & Total Biaya $(\mathrm{A}+\mathrm{B})$ & & 21.057.394,98,- \\
\hline & Krisan Standart Grade A & 19.790.078,20 & \\
\hline & Krisan Aster Grade A & 19.123.591,39 & \\
\hline & Krisan Grade B & $1.118 .249,30$ & \\
\hline D. & Penerimaan Usahatani Krisan Berbagai Grade & & $40.031 .918,89,-$ \\
\hline E. & Pendapatan $(\mathrm{D}-\mathrm{C})$ & & 18.974.523,90,- \\
\hline F. & $\mathrm{R} / \mathrm{C}$ Ratio $(\mathrm{D}: \mathrm{C})$ & & 1,90 \\
\hline
\end{tabular}

Sumber : Data Primer Diolah, 2018

\section{Biaya Variabel}

Biaya variabel merupakan biaya yang totalnya berubah-ubah secara proporsional sesuai banyaknya volume atau kapasitas yang akan diproduksi. Biaya Variabel yang digunakan petani responden terdiri dari bibit, pupuk kandang, pupuk kimia, pestisida, vitamin, isolasi, karet, dan kertas. Berikut adalah biaya variabel pada usahatani bunga Krisan potong. Berdasarkan Tabel 2 dapat diketahui rata-rata biaya penggunaan bibit per $1000 \mathrm{~m}^{2}$ adalah Rp. 10.383.147,06,-. Biaya rata-rata penggunaan pupuk kandang sebesar Rp. 577.502,92,-. Biaya rata-rata penggunaan pupuk kimia sebesar Rp. $364.990,87$,-.Untuk biaya pestisida rata-rata per $1000 \mathrm{~m}^{2}$ senilai $\mathrm{Rp} .474 .018,39$,- biaya vitamin rata-rata per $1000 \mathrm{~m}^{2}$ senilai Rp. $151.057,95,-$, biaya isolas rata-rata per $1000 \mathrm{~m}^{2}$ senilai $17.237,02$ rata-rata biaya penggunaan bibit per $1000 \mathrm{~m}^{2}$ adalah $44.419,18$ dan 
rata-rata biaya kertas per $1000 \mathrm{~m}^{2}$ sebanyak Rp. $576.470,00$,- serta rata-rata biaya tenaga kerja per $1000 \mathrm{~m}^{2}$ senilai Rp. 5.755.311,16,-

\section{Biaya Tetap}

Biaya tetap merupakan biaya yang tidak mempengaruhi oleh besarnya output yang dihasilkan. Biaya tetap meliputi biaya sewa lahan, Pajak, Listrik, dan penyusutan alat. Berdasarkan Tabel 2 maka dapat diketahui jumlah rata-rata biaya tetap yang digunakan oleh petani responden selama satu kali tanam dalam luas greenhouse $1000 \mathrm{~m}^{2}$ yaitu sebesar Rp. 2.701.500,-.

\section{Biaya Total}

Biaya total merupakan keseluruhan biaya yang dikeluarkan oleh petani responden yang meliputi biaya variabel (biaya tidak tetap) dan biaya tetap. Pada Tabel 2 menunjukkan bahwa biaya total yang dikeluarkan oleh petani responden yaitu rata - rata biaya per $1000 \mathrm{~m}^{2}$ sebesar Rp. 21.015.600,- dalam satu kali tanam.

\section{Penerimaan Usahatani Krisan Berbagai Grade}

Penerimaan merupakan pendapatan kotor yang diperoleh petani responden pada saat panen. Adapun penerimaan yang di dapat oleh petani Krisan terbagi menjadi tiga unsur yaitu penerimaan atas bunga Krisan tipe Standart grade A, Aster grade A, dan Grade B. Penerimaan penjualan bunga untuk petani diperoleh dari produksi hasil bunga dikalikan dengan harga sesuai grade. Grade A mempunyai panjang batang mulai $60 \mathrm{~cm}$. Grade B mempunyai panjang batang mulai $40 \mathrm{~cm}$. Berdasarkan Tabel 2 maka dapat diketahui rata-rata penerimaan bunga Krisan potong dalam satu kali tanam dengan luasan greenhouse $1000 \mathrm{~m}^{2}$ sebanyak Rp.40.031.900,--

\section{Pendapatan $(\pi)$}

Pendapatan merupakan penerimaan bersih yang diperoleh petani dengan cara menghitung total penerimaan dikurangi dengan total biaya yang dikeluarkan. Berdasarkan Tabel 2 menunjukkan pendapatan petani selama kurang lebih 3,5 bulan dalam sekali tanam bunga Krisan potong dengan luasan lahan $1000 \mathrm{~m}^{2}$ yaitu sebanyak Rp. 18.974.500,-.

\section{R/C Ratio}

Salah satu ukuran efisiensi suatu usaha adalah dapat dilihat dari rasio antara penerimaan penjualan dengan biaya-biaya yang dikeluarkan selama proses produksi. Perhitungan R/C ratio dapat diperoleh dari hasil bagi rata-rata penerimaan petani bunga Krisan potong dengan rata-rata total biaya yang dikeluarkan per $1000 \mathrm{~m}^{2}$. Tabel 2 menunjukkan bahwa nilai R/C ratio bunga Krisan potong Desa Sidomulyo yaitu sebanyak 1,90 Sehingga dari kriteria yang digunakan adalah jika $\mathrm{R} / \mathrm{C}$ ratio $>1$, artinya usahatani bunga Krisan potong tersebut efisien dan menguntungkan

\section{Faktor-Faktor yang Mempengaruhi Produktivitas}

Faktor-faktor yang mempengaruhi produktivitas bunga Krisan dapat dilihat dari hasil analisis untuk fungsi produksi rata-rata (mean production function) yaitu dengan memasukkan faktor produksi (bibit, pupuk kandang, pupuk kimia, pestisida dan tenaga kerja) sebagai variabel independen dan produktivitas bunga Krisan sebagai variabel dependen, diperoleh model pendugaan untuk fungsi produksi rata-rata bunga Krisan. Hasil pendugaan fungsi produksi rata-rata dapat dilihat pada Tabel 3. 
Tabel 3. Hasil Pendugaan Fungsi Produktivitas Usahatani Bunga Krisan

\begin{tabular}{lllll}
\hline Variable & Coefficient & Std. Error & Z-Statistic & Prob. \\
\hline LNX1 (Bibit) & $0,7000^{*}$ & 0,296404 & 2,361562 & 0,0254 \\
LNX2 (P. Kandang) & 0,0652 & 0,057493 & 1,134611 & 0,2662 \\
LNX3 (P. Kimia) & $-0,2747 * *$ & 0,077862 & $-3,527624$ & 0,0015 \\
LNX4 (Pestisida) & 0,0125 & 0,045291 & 0,275557 & 0,7849 \\
LNX5 (Tenaga Kerja) & $1,3970 * *$ & 0,093399 & 14,95692 & 0,0000 \\
Konstanta & $-9,8403$ & 3,194224 & $-3,080661$ & 0,0046 \\
R-sq = 89,52 persen & R-sq (adj) = 87,65 persen & Prob (F-stastistic) $=\mathbf{0 , 0 0}$
\end{tabular}

Keterangan $=* *)$ Signifikan 1 persen

*) Signifikan 5 Persen

Berdasarkan hasil pendugaan fungsi produktivitas pada Tabel 3 nilai produktivitas usahatani bunga Krisan potong dapat diduga dengan persamaan berikut:

Ln Produktivitas $=-9,8403+0,7000$ Ln Bibit $+0,0652$ Ln Pupuk Kandang 0,2747 Ln Pupuk Kimia + 0,0125 Ln Pestisida + 1,3970 Ln Tenaga Kerja

Berdasarkan nilai $R$-squared (adj) dapat diketahui bahwa bibit, pupuk kandang, pupuk kimia, pestisida, dan tenaga kerja dapat menjelaskan $87,65 \%$ terhadap variabel produktivitas bunga Krisan potong. Variabel yang tidak dapat dijelaskan oleh variabelvariabel tersebut sebesar $12,35 \%$. Hal ini disebabkan oleh faktor lain yang tidak masuk dalam model. Nilai F-hitung pada fungsi produktivitas dapat dilihat pada nilai prob (Fstatistic) yaitu sebesar 0,00 lebih kecil dari taraf nyata $0,05(\alpha=5 \%)$, maka hal ini menunjukkan bahwa bibit, pupuk kandang, pupuk kimia, pestisida, dan tenaga kerja secara bersam-sama berpengaruh sangat nyata terhadap produktivitas bunga Krisan potong pada taraf kepercayaan $95 \%$.

Setelah dilakukan perhitungan dengan menggunakan software Eviews 9 ternyata tidak semua variabel yang berpengaruh nyata pada taraf nyata 5 persen. Berdasarkan nilai P-Value dapat diketahui variabel independen (faktor produksi) mana saja yang berpengaruh signifikan terhadap produktivitas bunga Krisan potong. Jika nilai P-value lebih kecil dari taraf nyata $\alpha$ maka variabel tersebut berpengaruh signifikan. Variabel bibit, pupuk kimia dan tenaga kerja berpengaruh nyata pada taraf nyata 5 persen. Artinya faktor produksi tersebut berpengaruh nyata terhadap produktivitas bunga Krisan potong, sehingga jika terjadi penambahan atau pengurangan pada faktor produksi tersebut maka akan berpengaruh terhadap produktivitas bunga Krisan. Variabel pupuk kandang dan pestisida tidak berpengaruh nyata pada taraf nyata 5 persen terhadap produktivitas bunga Krisan. Jika terjadi penambahan atau pengurangan pada faktor produksi tersebut maka tidak akan berpengaruh terhadap produktivitas bunga Krisan.

\section{Bibit}

Bibit berpengaruh positif dan nyata $(\alpha=5 \%)$ terhadap bunga Krisan potong dengan koefisien sebesar 0,7. Artinya setiap penambahan bibit sebesar 1 persen akan menyebabkan kenaikan produksi bunga Krisan potong sebesar 0,7 persen (280 tangkai). Rata-rata penggunaan bibit sebesar 55.101 tangkai/1000m2. Banyak sedikitnya penggunaan bibit juga dipengaruhi oleh kualitas mutu bibit yang dipakai (daya tumbuh bibit). Para petani selalu mengusahakan membeli bibit yang bekualitas bagus meskipun harganya mahal. 
ISSN : 2622-6154 (print)

Penelitian ini mendukung penelitian terdahulu yang dilakukan oleh Zakirin et al (2013) dan Rama et al (2016) yang menunjukkan bahwa bibit berpengaruh nyata dan positif terhadap produksi padi di lokasi penelitiannya. Menurut penelitian Zakirin et al, (2013) peningkatan penggunaan benih dapat menaikkan produksi padi. Pada penelitian ini penggunaan bibit bunga dapat menaikkan produksi Krisan. Artinya bibit yang digunakan oleh petani sudah bagus.

\section{Pupuk Kimia}

Pupuk kimia berpengaruh negatif sangat nyata $(\alpha=1 \%)$ terhadap bunga Krisan potong dengan koefisien sebesar -0,2747. Artinya setiap penambahan pupuk kimia sebesar 1 persen $(0,4 \mathrm{Kg} / 1000 \mathrm{~m} 2)$ akan diikuti penurunan produksi bunga Krisan potong sebesar 0,27 persen (110 tangkai). Rata-rata penggunaan pupuk kimia di tingkat petani responden sebesar $40,65 \mathrm{Kg} / 1000 \mathrm{~m} 2$. Petani mengunakan berbagai macam pupuk kimia diantaranya ZA, NPK, Urea, dan SP36, pupuk kimia yang digunakan setiap petani responden sangat berbeda, dan ke empat pupuk tersebut tidak digunakan secara bersamaan melainkan ada waktu dan konsentrasinya sendiri-sendiri.

Hasil penelitian ini berbeda dengan penelitian yang dilakukan Zakirin et al, (2013), dan Rama et al, (2016) meneliti pupuk urea yang merupakan salah satu dari macam-macam pupuk kimia yang digunakan dalam usahatani bunga Krisan menyatakan bahwa pupuk urea berpengaruh signifikan dan positif terhadap produksi padi dan juga hasil penelitian Kurniati (2012) menyatakan bahwa pupuk urea berpengaruh signifikan dan positif terhadap produksi jagung. Hal ini menujukkan bahwa penggunaan pupuk urea dapat meningkatkan produktivitas padi maupun jagung di lokasi penelitiannya.

\section{Tenaga Kerja}

Tenaga kerja berpengaruh positif dan nyata $(\alpha=1 \%)$ terhadap bunga Krisan potong dengan koefisien sebesar 1,397. Artinya setiap penambahan tenaga kerja sebesar 1 persen akan diikuti kenaikan produksi bunga Krisan potong sebesar 1,397 persen (560 tangkai). Rata-rata tenaga kerja yang digunakan dalam usahatani ini sebesar 99 $\mathrm{HKSP} / 1000 \mathrm{~m}^{2}$. Tenaga kerja yang digunakan dalam usahatani bunga Krisan potong yaitu terdiri dari tenaga kerja dari luar keluarga dan dalam keluarga.

Penelitian ini mendukung penelitian terdahulu yang dilakukan oleh Rama et al (2016) yang menyatakan bahwa penambahan tenaga kerja masih bisa meningkatkan produksi padi, terutama tenaga kerja untuk pemeliharaan tanaman yang membutuhkan tenaga kerja manusia.

\section{Faktor-Faktor yang Mempengaruhi Risiko Produksi Bunga Krisan Potong}

Faktor produksi bunga Krisan tidak hanya berpengaruh terhadap produktivitas bunga Krisan tetapi juga berpengaruh terhadap risiko produksi bunga Krisan. Pengaruh faktor produksi terhadap risiko produksi dapat dijelaskan dari hasil pendugaan persamaan fungsi risiko produksi dapat dilihat pada Tabel 4.

Berdasarkan hasil pendugaan risiko produksi pada Tabel 4 maka risiko produksi usahatani bunga Krisan potong dapat diduga dengan persamaan berikut:

Ln Produktivitas $=$ 0.166-0,027 Ln Bibit + 0,010 Ln Pupuk Kandang + 0,037 Ln

Pupuk Kimia-0,003 Ln Pestisida -0.005 Ln Tenaga Kerja 
ISSN : 2622-6154 (print)

Tabel 4. Hasil Pendugaan Persamaan Fungsi Risiko Produksi Bunga Krisan

\begin{tabular}{lllll}
\hline Variable & Coefficient & Std. Error & z-Statistic & Prob. \\
\hline \hline LNX1 (Bibit) & $-0,027520$ & 0,067407 & $-0,408262$ & 0,6862 \\
LNX2 (P. Kandang) & 0,010039 & 0,013075 & 0,767778 & 0,4490 \\
LNX3 (P. Kimia) & $0,037835^{*}$ & 0,017707 & 2,136731 & 0,0415 \\
LNX4 (Pestisida) & $-0,003149$ & 0,010300 & $-0,305745$ & 0,7621 \\
LNX5 (Tenaga Kerja) & $-0,005587$ & 0,021240 & $-0,263041$ & 0,7944 \\
Konstanta & 0,66189 & 0,726414 & 0,228780 & 0,8207
\end{tabular}

R-sq $=23,39$ persen $\quad$ R-sq $($ adj $)=09,70$ persen $\quad$ Prob $($ F-stastistic $)=0,17$

Keterangan $=* *)$ Signifikan 1 persen

*) Signifikan 5 Persen

Berdasarkan nilai adjusted $R$-squared diketahui bahwa bibit, pupuk kandang, pupuk kimia, pestisida, dan tenaga kerja dapat menjelaskan 9,7\% terhadap risiko produksi bunga Krisan potong. Variabel yang tidak dapat dijelaskan oleh variabelvariabel tersebut sebesar 90,3\%. Hal ini disebabkan oleh faktor lain yang tidak masuk dalam model. Nilai F-hitung pada fungsi produktivitas dapat dilihat pada nilai prob (Fstatistic) yaitu sebesar 0,17 lebih besar dari taraf nyata $0,05(\alpha=5 \%)$, maka hal ini menunjukkan bahwa bibit, pupuk kandang, pupuk kimia, pestisida, dan tenaga kerja secara bersama-sama tidak berpengaruh nyata terhadap risiko bunga Krisan potong pada taraf kepercayaan $95 \%$.

Setelah dilakukan perhitungan dengan menggunakan software Eviews 9 ternyata tidak semua variabel yang berpengaruh nyata pada taraf nyata 5 persen. Berdasarkan nilai P-Value dapat diketahui ( faktor produksi yang berpengaruh signifikan terhadap produktivitas bunga Krisan potong. Jika nilai P-value lebih kecil dari taraf nyata maka variabel tersebut berpengaruh signifikan. Variabel pupuk kimia berpengaruh nyata pada taraf nyata 5 persen, artinya faktor produksi tersebut merupakan faktor yang dapat meningkatkan risiko produksi atau menurunkan risiko produksi. Jika terjadi penambahan atau pengurangan pada faktor produksi tersebut maka berpengaruh terhadap risiko produksi bunga Krisan. Sedangkan variabel bibit, pupuk kandang pestisida, dan tenaga kerja tidak berpengaruh nyata pada taraf nyata 5 persen terhadap risiko produksi bunga Krisan. Jika terjadi penambahan atau pengurangan pada faktor produksi tersebut maka tidak akan berpengaruh terhadap risiko produksi bunga Krisan.

\section{Pupuk Kimia}

Koefisien pupuk kimia bertanda positif dan berpengaruh signifikan terhadap risiko produksi bunga Krisan potong pada taraf nyata 0,5 persen. Hal ini ditunjukkan dari nilai probabilitas terhadap risiko produksi yaitu memiliki peluang sebesar 0,0415 artinya setiap penambahan pupuk kimia akan mengakibatkan peningkatan risiko produksi bunga Krisan potong. Nilai koefisien variabel pupuk kimia yaitu sebesar 0,0378 , artinya setiap penambahan jumlah pupuk kimia sebesar 1 persen $(0,4$ $\mathrm{Kg} / 1000 \mathrm{~m}^{2}$ ) akan meningkatkan risiko produksi bunga Krisan sebesar 0,0378 persen (menurunkan produksi sebanyak 16 tangkai) dengan asumsi variabel produksi lainnya tetap. Faktor produksi pupuk kimia dapat dikatakan sebagai faktor peningkat risiko (risk inducing factors).

Pendugaan fungsi produksi rata-rata sebelumnya menjelaskan bahwa pupuk kimia dapat menurunkan produktivitas rata-rata secara nyata. Penurunan produktivitas bunga 
Krisan potong ini menyebabkan risiko produksi menjadi semakin besar sehingga pupuk kimia bertindak sebagai faktor yang dapat menimbulkan risiko. Hal ini disebabkan penggunaan pupuk kimia oleh petani responden yang terlalu banyak dan petani responden harus berhati-hati dalam penggunaan pupuk kimia yang berlebihan ini karena dapat menyebabkan tanaman menjadi keracunan dan mati sehingga dapat menurunkan produksi. Selain itu harga pupuk kimia per kg yang relatif lebih mahal jika dibandingkan dengan harga input yang digunakan lainnya. Hasil penelitian ini berbeda dengan penelitian Kurniati (2012), Zakirin et al (2013), dan Rama et al (2016) yang menyatakan bahwa pupuk kimia berpengaruh positif namun tidak signifikan terhadap risiko produksi.

\section{KESIMPULAN}

Secara bisnis, usahatani bunga Krisan potong merupakan usaha yang menarik untuk diusahakan karena dapat memberikan keuntungan yang cukup besar bagi petani Nilai pendapatan total yang diperoleh petani responden yakni sebesar 18.974.523,90 per $1000 \mathrm{~m} 2$ dan R/C Ratio sebesar 1,9 yang artinya menguntungkan dan efisien.

Hasil parameter fungsi produktivitas menunjukkan tidak semua input produksi berpengaruh signifikan. Faktor produksi yang berpengaruh signifikan terhadap produktivitas Bunga Krisan potong yaitu bibit, pupuk kimia, dan tenaga kerja. Sedangkan input produksi yang tidak berpengaruh signifikan terhadap produktivitas adalah pupuk kandang dan pestisida.

Pendugaan fungsi produksi rata-rata menjelaskan bahwa pupuk kimia dapat menurunkan produktivitas. Penurunan produktivitas bunga Krisan potong ini menyebabkan risiko produksi menjadi semakin besar, sehingga pupuk kimia menjadi faktor yang dapat menimbulkan risiko. Penyebabnya adalah penggunaan pupuk kimia oleh petani terlalu banyak. Rekomendasi yang diberikan adalah petani harus mengurangi penggunaan pupuk kimia. Petani juga harus berhati-hati dalam penggunaan pupuk kimia yang berlebihan karena dapat menyebabkan tanaman keracunan dan mati sehingga menurunkan produksi. Selain itu harga pupuk kimia yang mahal maka pengurangan penggunaan pupuk kimia akan mengurangi biaya produksi Bunga Krisan.

\section{DAFTAR PUSTAKA}

Ariefianto, M. Doddy. 2012. Ekonometrika : esensi dan aplikasi dengan menggunakan eviews. Jakarta: Erlangga.

Astaningrum, J. A., \& Djuwendah, E. (2015). Analisis Risiko Usahatani Bunga Krisan Potong, $3,1-8$.

[BPS] Badan Pusat Statistik. 2016. Hortikultura Malang: Badan Pusat Statistik.

[BPS] Badan Pusat Statistik Provinsi Jawa Timur. 2016. Produktivitas bunga Krisan potong di Jawa Timur dalam Angka. Malang: Badan Pusat Statistik Provinsi Jawa Timur.

Darmansyah, E., Muani, A., \& Radian. (2017). Analisis Risiko Produksi Usahatani Jeruk Siam Pontianak di Kabupaten Sambas, 6, 13-23.

Darwanto, D. H., \& Mulyo, J. H. (2011). Analisis Risiko Produksi Usahatani Kedelai pada Berbagai Tipe Lahan di Sulawesi Selatan, 8.

Debertin, DL. 1986. Agricultural Production Economics. New York: Mcmillan Publishing Company.

Fanani, A., Anggraeni, L., \& Syaukat, Y. (2015). Pengaruh Kemitraan Terhadap Risiko Usaha Tani Tembakau di Kabupaten Bojonegoro Provinsi Jawa Timur, 12, 194-203. 
ISSN : 2622-6154 (print)

https://doi.org/10.17358/JMA.12.3.194

Harwood, J., Heifner, R., Coble, K., Perry, J., \& Somwaru, A. (1999). Managing risk in farming: concepts, research and analysis. Agricultural Economic Report No. 774, (774), 83.

Hidayati, R., Fariyanti, A., \& Kusnadi, N. (2015). Analisis Preferensi Risiko Petani Pada Usahatani Kubis Organik di Kecamatan Baso, Kabupaten Agam, Sumatera Barat, 3, 2538.

Kurniati, D. (2012). Analisis Risiko Produksi dan Faktor-Faktor yang Mempengaruhinya pada Usahatani Jagung (zea mays L.) di Kecamatan Mempawah Hulu Kabupaten Landak, 1, $60-68$.

Lawalata, M., Darwanto, D. H., \& Hartono, S. (2017). Risiko Usahatani Bawang Merah di Kabupaten Bantul, 10, 56-73.

Lipsey RG, Courant PN, Purvis DD, Steiner PO. 1995. Pengantar Mikroekonomi. Ed ke-10. Jakarta: Binarupa Aksara

Rama, R., Nurliza, \& Dolorosa, E. (2016). Analisis Risiko Produksi Usahatani Padi Lahan Basah dan Lahan Kering di Kabupaten Melawi, 5, 73-88.

Rinaldy, J., \& Arya, Nyoman Ngurah, S. (2015). Analisis Risiko Produksi Usahatani Padi Sawah di Provinsi Bali, 1.

Soekartawi, Rusmadi, D. Effi. 1993. Risiko dan Ketidakpastian dalam Agribisnis. Jakarta: Raja Grafindo Persada

Soekartawi. 1990. Teori Ekonomi Produksi: dengan pokok bahasan analisis fungsi CobbDouglass. Jakarta: Raja Grafindo Persada.

Soekartawi. 2002. Analisis Usahatani. Jakarta: UI-press.

Tveterås, R. (1999). Production Risk and Productivity Growth: Some Findings for Norwegian Salmon Aquaculture. Journal of Productivity Analysis, 12(2), 161-179. https://doi.org/10.1023/A:1007863314751

Verbeek, M. (2004). A Guide to Modern Econometrics. Text. https://doi.org/10.1017/CBO9781107415324.004

Zakirin, M., Yurisinthae, E., \& Kusrini, N. (2013). Analisis Risiko Usahatani Padi pada Lahan Pasang Surut di Kabupaten 